PROSE

\title{
The Shrunken Giant
}

\section{Nick Cowling}

THE BASTARD WAS a pillar, a towering figure in my life. When I was much younger he appeared to be carved out of rock, etched from stone. Unshakeable and immoveable. Whenever he spoke it was with conviction, authority, and arrogance; everyone in the room would shut up when he opened his mouth and take his word like it was gospel. In the mid 90s long before Wikipedia - he was a living reference. No matter how outlandish the things he said were, it was known that if Pat said it, it MUST be true.

This was my Dad.

Being the age that I was then, I looked up to him. I wanted to make him love me, to prove myself to him. I never understood how he could say he loved seeing me on the weekends, and then spend the rest of the weekend drinking and smoking with his friends. On the Sunday afternoons when mum came to pick me up she would ask me how my weekend was, "good" was always the reply as I tried to figure out if I had actually enjoyed myself. No doubt, I had enjoyed watching TV. I had enjoyed reading the books and magazines scattered through his house. I had enjoyed the movies and take away we got from the shops in Seddon. And I really enjoyed the toys he would occasionally buy me.

But I never directly enjoyed him.

Memories of that time drift in and out; always just out of reach or painfully in focus. I remember him shifting houses a fair bit; always in the same area just different places. I never thought it was weird I just thought to myself: that's Dad for you. His persistent hacking cough 
didn't concern me. I was seven at the time and far from having any kind of understanding of medical science; that was mum's job. Back in those days I was more interested in sharks and Power Rangers. I was also too afraid of getting yelled at to say anything. I didn't even ask when Dad told me that I was being shifted out of my room for him to grow 'plants'. I only saw my room at that place a couple more times. I never understood why there was foil on the windows.

As I got older I got more and more aware of Dad's vices. Sleepovers at friend's houses showed me that regular Dads didn't engage in the same behaviour Dad did. I never understood it and he would always give me some bullshit excuse like: "It's just like a puff of a cigarette," and then the conversation would be changed very, very quickly. When we went out it wouldn't be for too long; Dad would always rush home. We did do things though; trips to the museum and the shops did happen, but they were limited enough that it would be very memorable for actually happening.

Dad's addictions continued to follow him through his life, and mine. While his intake of drugs and alcohol increased, I never experimented. I only had my first drink after I turned eighteen. I felt strong waves of resentment towards him for the childhood he knowingly exposed me to. How could you be so selfish and reckless while looking after your own son? His addictions never directly threatened my life, but it is still far from responsible behaviour. He didn't care about being a role model; he was only concerned with sating his own desires. My disgust at his lifestyle and desire to distance myself from him only grew with time.

Oncology was a word I had never heard before in my life, then all of a sudden it was on my phone as a text message with a return number. It was an alien word steeped in foreboding. It just sounded bad. Jumping out of class, I called the number back and found myself talking to an oncology specialist at the Western General Hospital. As she spoke, the world melted and warped around me. I was swimming in the middle of the corridor. Words like 'massive stroke', 'heart attack' and 'memory loss' were mentioned, along with 'sizable lump on the lung' and 'inoperable'. Tears streaming down my face, I asked the voice on the other end of the line how much time he had left. The voice replied weeks, maybe months. Gravity disappeared, the magnetic 
poles inverted, nothing was right. I collected my things and left for the hospital.

I spent the next two weeks by my Dad's bedside.

When I got to the hospital I was afraid to see him. I had never seen anyone who had cancer before. After bracing myself I slowly propelled myself into his room. I didn't know what I was expecting, but it was nowhere near as terrible as what I was confronted with. The giant of my youth had been whittled away by age and lifestyle. Seeing him on that bed; shriveled and frail, I felt like Luke Skywalker towards the end of Return of the Fedi where he sees what Darth Vader looks like under the helmet. All the anger, hate and built-up resentment I had for this 'man' in front of me dissipated immediately. When it came down to brass tacks he was, and always will be, my Dad. The fear and horror I was experiencing at the time would have nothing in comparison to what he was feeling.

Or so I thought.

Whenever I tried to broach the subject with him he just gazed at me with unfocused eyes, shrugged his shoulders and said: "C'est la vie." Even though he was dying, even though he was in indescribable pain, I hated him at that moment all over again. Here was a man, who in his moments of lucidity stressed to me the importance of fighting to be yourself. A man who advocated against taking the path of least resistance. Here he was, in my eyes, rolling over and letting the lung cancer win. This was inexcusable. I wanted to shake him. I wanted to pick him up and throw him against the wall. I wanted him to live.

I spent as much time with him as I could manage. Uni, work, my social life all took a back seat to comforting my Dad and sorting out all of his affairs. I didn't make any time to care for myself. When Dad is seen to I will look after myself became my daily mantra. I had to keep repeating it to myself as he deteriorated at an accelerated rate. It was hard enough when he couldn't stand by himself but seeing him struggle to eat and breathe was heartbreaking. That choking, raspy, drawn-out inhale and exhale will haunt my life until I die. The cancer was literally choking him to death.

When he eventually died it felt like a relief. Seeing him being kept alive without any chance for recovery or treatment felt like a punishment, and he did not deserve this suffering. I asked every doctor who consulted him what the point to keeping him alive was if he was 
going to die anyway? Every response was the same: "We are trying to ease his pain, make him comfortable. It's all we can do for him now." I saw him the night before he passed; unconscious yet still yelping in pain with every breath. He was so drenched in sweat I could be forgiven for thinking he had taken a shower with his clothes on. The hospital staff had turned the air conditioner to a low setting, making the room feel like a tomb. By this point he was in palliative care. Despite his stroke in the days leading up to his last he was remarkably self-aware. He knew the end was nigh.

Dad was cremated. A week or two after the service my uncle, aunt, girlfriend, mother, and I took Dad's ashes down to The Warmies, a fishing spot my Dad and his brother used to haunt in their youth. While we were there my uncle regaled us with a story about how they would 'fish' for discarded hooks, lures, and sinkers that had been discarded at the bottom of the water. When they recovered them they would re-sell them to the fishermen at The Warmies and make a quick buck. We all had a quiet laugh at Dad's entrepreneurial spirit.

I cast Dad's ashes into Port Phillip Bay knowing in my heart that I could never return there easily. "Goodbye, Dad," I muttered as he sunk into the water. Then all of a sudden it hit me. All of the things I had been holding off feeling came flooding to the surface. All the unanswered questions: How could he have done this to himself? How could he have done this to me? Why didn't I spend more time with him? For months after he died I was plagued by my own lack of interest in his life. Had I chosen to leave or had he forced me away? If I had only stuck it out and had the slightest extended contact with him he would still be alive. The dead always leave loose threads; pulling them is what drives the living insane. After a few months I made the choice to stop looking for threads, and the world didn't seem so dark anymore. 